\title{
Synthesis of some Nano Multi Arms Polylactide-Dipentaerythritol Organic Polymers
}

\author{
Baqer Al-Mayahi, Hadi Al-Lami*, Athir Haddad \\ Department of Chemistry, College of Science, University of Basrah, Basrah-Iraq \\ *Corresponding author: Hadi Salman Al-Lami, email: hadisalman54@yahoo.com mobile: +9647901681631
}

Received March 30 ${ }^{\text {th }}, 2020$; Accepted July $6^{\text {th }}, 2020$.

DOI: http://dx.doi.org/10.29356/jmcs.v64i4.1182

\begin{abstract}
The synthesis of a family of polymer stars with six arms of varied poly (L-lactide), PLLA, chain length were prepared to have four various L-lactide monomer repeated units $(x=10,25,50$, and 100) of Llactide with Dipentaerythritol (DPE) cores support six PLLA arms using 1,8-Diazabicyclo [5.4.0] undec-7-ene (DBU) as an organocatalyst in the ring-opening polymerization (ROP), which afford systematic control the ROP to synthesize polymer stars of variable molecular weight at room temperature. The proposed polymerization mechanism was driven by hydrogen bonding interaction. This is following the fact that DBU does not cause extensive transesterification of PLLA on the time scale of lactide ROP.

The well-defined six-armed stars (PLLA) with a DPE core has been proven by FTIR (Fourier-Transform Infrared Spectroscopy), ${ }^{1} \mathrm{H}-\mathrm{NMR}$ (Proton Nuclear Magnetic Resonance Spectroscopy), ${ }^{13} \mathrm{C}-\mathrm{NMR}$ (Carbon Nuclear Magnetic Resonance Spectroscopy), and GPC (Gel Permeation Chromatography). The analysis of these six-arm polymers confirmed the expected structure of the obtained star-shaped polymers. The molecular weights of D-PLLAx star polymers linearly increased with the molar ratio of monomer to the initiator, and the molecular weight distribution was narrow $(\mathrm{Mw} / \mathrm{Mn}=1.09-1.13)$. The scanning electron microscope (SEM) was used to examine the shape and size of the prepared stars D-PLLAx polymeric nanoparticles may form. The micrographs revealed that the nanoparticles with nearly spherical shapes and with different sizes were gained, but in general, they are less than $100 \mathrm{~nm}$ in diameters as they developed by the Image-J program which may have a great impact on star properties, The simplicity of the reaction conditions, the ready availability of the catalyst, and the exquisite control over the polymerization are demonstrated.
\end{abstract}

Keywords: Organic polymer; dipentaerythritol; nanoparticles; polylactide six arms.

Resumen. Se reporta la síntesis de una familia de polímeros tipo estrella, los cuales contienen una estructura de seis brazos de unidades de poli (L-lactida), PLLA, de longitud de cadena variada. Los polímeros contienen cuatro diferentes tamaños de unidades repetitivas de monómero de L-lactida $(\mathrm{x}=10,25,50 \mathrm{y} 100)$, con una coraza de dipentaeritritol (DPE), lo cual implica la formación de un polímero de PLLA conteniendo seis brazos. Se utiliza 1,8-diazabiciclo [5.4.0] undec-7-eno (DBU) como organocatalizador en la polimerización por apertura de anillo (ROP), lo que permite un control sistemático en la polimerización que permite sintetizar polímeros estrellas de peso molecular variable a temperatura ambiente. El mecanismo de polimerización propuesto implica la aceleración de la reacción debido a la formación de enlaces de hidrógeno. Otra ventaja es que el uso de DBU no da lugar a un proceso de transesterificación extenso del PLLA en la escala de tiempo en que ocurre la apertura del anillo de lactida.

Los polímeros estrella de seis brazos de PLLA con un núcleo DPE se caracterizaron por FTIR (Espectroscopía infrarroja por transformada de Fourier), ${ }^{1} \mathrm{H}-\mathrm{NMR}$ (Espectroscopía de resonancia magnética nuclear de protones), ${ }^{13} \mathrm{C}-\mathrm{NMR}$ (Espectroscopía de resonancia magnética nuclear de carbono), y GPC (cromatografía de permeación en gel). Mediante estas técnicas se corrobora la obtención de polímeros de seis brazos que tienen 
una estructura en forma de estrella. Los pesos moleculares de los polímeros estrella D-PLLAx aumentaron linealmente con la relación molar de monómero a iniciador, con una distribución de pesos moleculares estrecha $(\mathrm{Mw} / \mathrm{Mn}=1,09-1,13)$. El microscopio electrónico de barrido (SEM) se utilizó para examinar la forma y el tamaño de las nanopartículas polímericas de D-PLLAx tipo estrella preparados. Las micrografías revelaron que se obtienen nanopartículas con formas casi esféricas y con diferentes tamaños, pero en general, con menos de $100 \mathrm{~nm}$ de diámetro, tal y como se deduce del análisis hecho por el programa Image-J, lo que se espera tenga un impacto importante en las propiedades de los polímeros estrella. Este artículo implica la aplicación de un método simple, el uso de un catalizador facilmente disponible y el adecuado control sobre la reacción de la polimerización.

Palabras clave: Polímero orgánico; dipentaeritritol; nanopartículas; polilactida de 6 brazos.

\section{Introduction}

Organic polymers are the most applicable type of polymers needed for various applications and can be prepared by different means. Ring-opening polymerization (ROP) is a type of chain-controlled polymerization used recently for cyclic organic monomers. The main advantage of ROP is its living nature and the strict control of the polydispersity index (PDI). The livingness being a prominent feature of ROP; the number of active and dormant (reversibly terminated) chains is generated instantaneously and remains constant during the polymerization reaction, therefore, it is always offering additional cyclic monomers to extend polymer chains $[1,2]$. ROP is an important method of polymerization to make some interesting and valuable polymers to suit different demands and requests [3] and multi-arm can be prepared depending on the type of initiator used [4]. The ROP is the preferred route for preparing the high molecular weight PLLA in industries. Poly (lactic acid) PLA, and polylactide PLLA, show promise as a valuable alternative to petroleum-based polymers for uses as plastics, fibers, and coatings [5]. They are produced from renewable resources such as corn and sugar beets, and the material is biodegradable along these lines, making it perfect for modern uses in industry and medicine $[6,7]$.

The most frequently reported controlled ROP of cyclic monomers in the literature [8,9] are coordination-insertion, anionic, cationic, and nucleophilic polymerization. The coordination-insertion and nucleophilic polymerization are undoubtedly the most efficient and general methods reported so far for the ROP of lactones, with cationic and anionic polymerization being much less investigated, while coordination-insertion polymerization uses metal-alkoxides and related complexes as catalysts. The successful ROP of lactide to make the biodegradable polymer polylactide was carried out by Robert and Aubrecht using tin (II) bis (2-ethyl hexanoate)/benzyl alcohol mediated ring-opening polymerization of lactide to form the biodegradable polylactide polymer. They found that the system of the polymerization is practically equivalent to that of a transesterification reaction. The influence of the water formation on the number-average molecular weight of the resulting polymer and the polymerization rate is also discussed [10].

An organocatalytic nucleophilic polymerization is a metal-free approach to ROP [11-13]. The proposed polymerization pathway differs fundamentally from the coordination-insertion mechanism involving metal complexes [14]. Metal-free catalysts, like enzymes and organocatalysts, are attracting growing interest as reported by Dubois et al. [11] since being considered to be the more economical and environmentally friendly alternatives. Indeed, the nucleophilic catalyst only activates the monomer toward ring-opening, whereas the metal complex activates the monomer, initiates the polymerization and remains bound to the growing chain. Dove et al. [15] reported the catalytic activity of a conjoined thiourea-tertiary amine molecule, in the ROP of lactide. Mechanics and theoretical studies support a supramolecular bifunctional mechanism involving activation of both the monomer and the alcohol nucleophile; polymerization is significantly slower with reaction times of a few days.

Rostami et al. [16] announced utilizing a tertiary aminosquaramide bifunctional organocatalyst, which is known as a catalyst-free of the metal producing a polymer having narrow PDI $(\approx 1.05)$. The low PDI's with uncommon control prominent is a result of specific transesterification of lactide comparative with the aliphatic esters. Practical and theoretical investigations enhance using such type of these functional components, 
increasing reactivity of alcohol nucleophile and the monomer. Screening studies demonstrated that a variety of thiourea-amine combinations are catalytically active for the ROP of lactide, and the structural flexibility and efficacy of thiourea-amine catalysts for the supramolecular activation and ROP of lactide are described again examined further by Pratt et al. [17] and Kazakov et al. [18]. They proposed that the polymerization was motivated by hydrogen bonding interaction, and these types of catalysts are regularly utilized for wellcontrolled ROP.

Mezzasalma et al. [19] reported the ring-opening polymerization (ROP) of L-lactide using different organocatalysts in solvent-free conditions at high temperatures (in bulk) has proven to be a significant challenge. Indeed, the high required temperature $\left(180^{\circ} \mathrm{C}\right)$ has led to poorly controlled polymerizations as a result of transesterification reactions of the polylactide backbone, racemization of the lactide monomers as well as the degradation and thus deactivation of the organocatalyst.

The 1,8-Diazabicyclo [5.4.0] undec-7-ene (DBU) catalyzed ROP of L-lactide was tested in $\mathrm{CDCl}_{3}$ at room temperature at a 100:1:1 monomer/catalyst/ initiator ratio [20], and the resulting polymer was found to have $\mathrm{Mn} 21,000 \mathrm{~g} / \mathrm{mol}$ and polydispersity $(\mathrm{PDI}=\mathrm{Mw} / \mathrm{Mn}) 1.05$. The molecular mass of the poly (lactide) could be controlled by varying the monomer/initiator ratio of 50:1 to 500:1 with a good correlation of the targeted and experimental Mn values with PDI less than 1.1. Qian et al. [21] used DBU as a known, effective, and convenient organocatalyst for the ring-opening polymerization of cyclic esters, to synthesize random copolymers of lactide and glycolide. Graft copolymerization of L-lactide onto chitosan was also carried out at room temperature by ring-opening polymerization using DBU under a nitrogen atmosphere to prepare chitosang-poly(N-lactide) graft copolymer. It was obtained in good yield and the success of the grafting process was checked by characterizing the grafted chitosan by FTIR [13].

Recently, it is observed an increased interest in star-shaped polylactide materials as they exhibit highly desirable rheological, mechanical, and biomedical properties that are inaccessible in the case of linear polymers. These branched polyesters have a higher concentration of functional end-groups that additionally influenced their properties and are expected to exhibit good degradation and controlled drug release properties $[22,23]$.

The aim of the work reported in this paper was the synthesis of a series of high-molar-mass sixarmed containing PLLA segments built on a core molecule of the dipentaerythritol (D-PLLA's) in ring-opening polymerization. The elaborated method of the preparation of star polymers, using DBU as a non-metal catalyst, i.e. organocatalyst, at room temperature will be advanced the applications of these star polymers. Characterization of these star polymers using FTIR spectroscopy, ${ }^{1} \mathrm{H}-\mathrm{NMR}$ and ${ }^{13} \mathrm{C}-\mathrm{NMR}$ spectroscopy, gel permeation chromatography (GPC), and SEM allows us to observe the relationship between microstructure and macrostructure control in these systems. Nevertheless, this work is based on synthetic, novelty indicating that some polymer characteristics can be controlled by the sensible choice of using ROP in the presence of a DBU catalyst at room temperature. Significantly, this will possibly establish a useful starting point not only to improve the physical properties of the star poly (L-lactide) in comparison to linear poly (L-lactide) [24,25] but also to generate biodegradable nanoparticles with adjustable sizes may be useful for targeted drug release.

\section{Experimental}

\section{Materials}

N,N-Dimethylformamide (DMF) (Assay $\geq 99.8 \%$ ) and Dichloromethane (DCM) (Assay $\geq 99.5 \%$ ) were supplied by MACRON Company. Dipentaerythritol, L-Lactide, 1,8-Diazabicyclo [5.4.0] undec-7-ene (DBU), and Magnesium sulfate were supplied by Sigma-Aldrich Company.

\section{Instruments}

The ${ }^{1} \mathrm{H}$-NMR and ${ }^{13} \mathrm{C}-\mathrm{NMR}$ spectra were recorded using Agilent DDR2 $500 \mathrm{MHz}$ NMR spectrometers, FTIR spectra were recorded using Nicolet IR-42, Mid-IR spectrometer. The prepared polymers were examined under Scanning electron microscope type JEOL 7500F supplied by JEOL Company, USA. Available at Department of Chemistry/Michigan State University. 
Polymers molecular weights and molecular weight distributions (Mw/Mn) were determined using a Waters 1515 gel permeation chromatography (GPC) equipped with a refractive index detector (Waters 2412), DMF was used as the eluent at a flow rate of $1.0 \mathrm{~mL} / \mathrm{min}$ and calibrated with poly (methyl methacrylate) standard, which is available at Department of Chemistry/Michigan State University.

\section{Preparation of Dipentaerythritol-lactide Polymer (D-PL 10$)$}

Dipentaerythritol $(0.508 \mathrm{~g}, 0.002 \mathrm{~mol})$ and L-lactide $(8.6478 \mathrm{~g}, 0.06 \mathrm{~mol})$ were dissolved in DMF at room temperature. After stirring for 5 minutes under Nitrogen atmosphere, DBU $(90 \mu \mathrm{L})$ was added into the mixed solution. The reaction was kept under Nitrogen for $2 \mathrm{~h}$. The reaction was stirred for a further $24 \mathrm{~h}$ at room temperature. Afterward, the reaction was worked up by the slow addition of the reactants to $500 \mathrm{~mL}$ distilled water to precipitate the polymer which was then filtered on Buchner funnel and washed with distilled water and then the filtrate was dissolved in DCM and dried over magnesium sulfate and filtered. The polymer was recovered through the column chromatography with silica gel, DCM was removed by rotary evaporator and the polymer was dried in a vacuum oven at $25^{\circ} \mathrm{C}$ for 24 hours [26]. The product was viscous with a yield of $79 \%$.

The same procedure was carried out to prepare polymers D-PL $25, \mathrm{D}-\mathrm{PL}_{50}$ and $\mathrm{D}-\mathrm{PL}_{100}$, Table 1 lists the quantities of reactants used in the preparation and the chemical equations can be represented by Scheme 1 of these polymers.

Table 1. The amounts of reactants utilized in the synthesis of D-PL ${ }_{(10-100)}$ and the physical state of the resulting polymers.

\begin{tabular}{|c|c|c|c|c|c|c|c|}
\hline \multirow{2}{*}{$\begin{array}{l}\text { Polymer } \\
\text { Code }\end{array}$} & \multicolumn{2}{|c|}{ Dipentaerythritol } & \multicolumn{2}{|c|}{ L-lactide } & \multirow{2}{*}{$\begin{array}{l}\text { DBU } \\
(\mu L)\end{array}$} & \multirow{2}{*}{$\begin{array}{c}\text { Yield } \\
(\%)\end{array}$} & \multirow{2}{*}{$\begin{array}{c}\text { Physical } \\
\text { State }\end{array}$} \\
\hline & Wt. (g) & Mol & Wt. (g) & Mol & & & \\
\hline D-PLLA $_{25}$ & 0.254 & 0.001 & 10.8 & 0.075 & 100 & 79 & Viscous \\
\hline D-PLLA $_{50}$ & 0.102 & 0.0004 & 8.6478 & 0.06 & 90 & 83 & Viscous \\
\hline D-PLLA $_{100}$ & 0.0508 & 0.0002 & 8.6478 & 0.06 & 90 & 87 & Solid \\
\hline
\end{tabular}

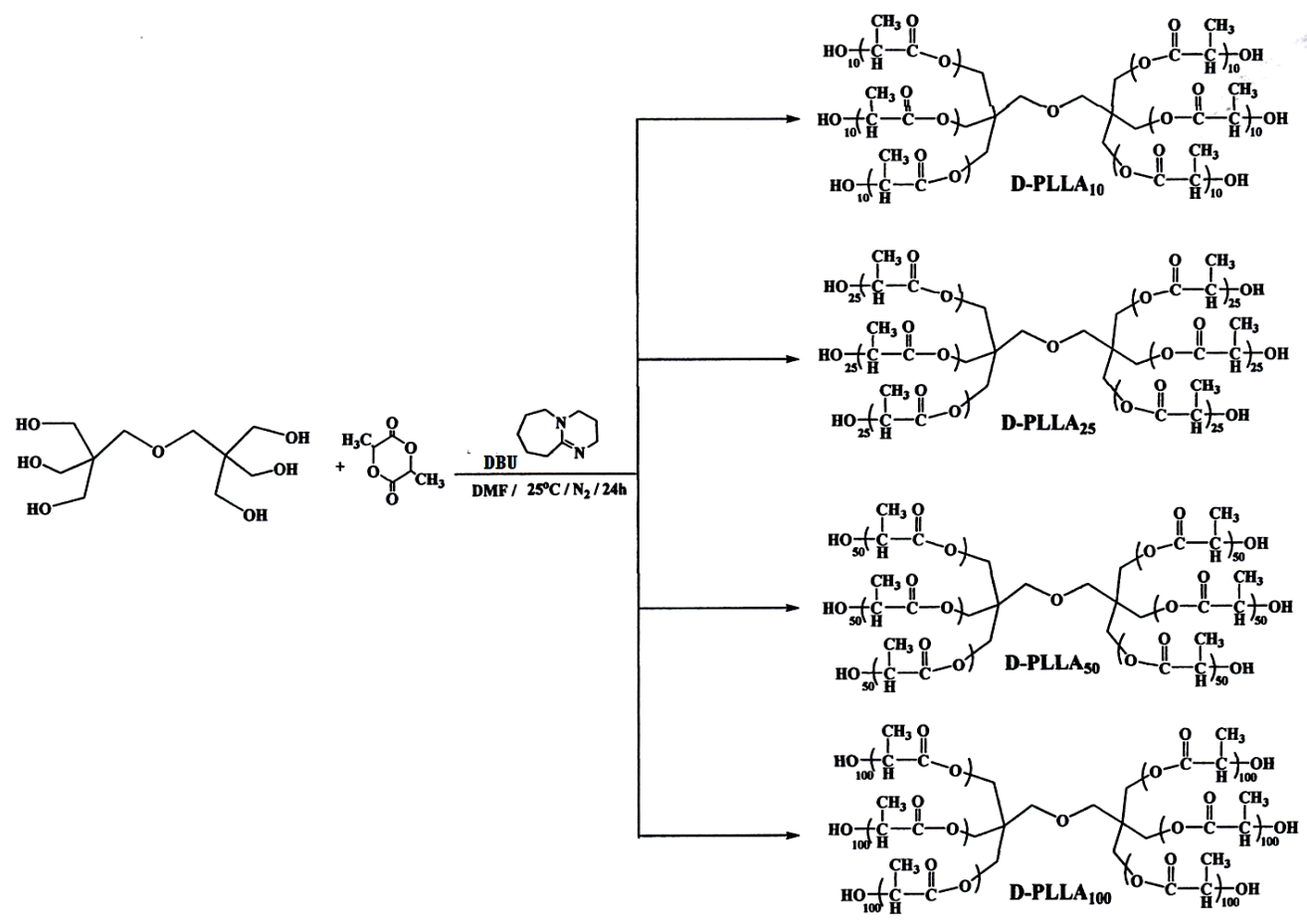

Scheme 1. Preparation of the D-PLLA 10 , D-PLLA 25, D-PLLA $_{50}$ and D-PLLA 100 polymers. 


\section{Results and discussion}

\section{Synthesis of controlled six arms star-shaped poly(L-lactide)}

Over the last ten years, there has been a huge increase in the development and applications of organocatalysis in which the catalyst acts as a nucleophile. Amidines and guanidines are often only thought of as strong organic bases, however, a number of small molecules containing basic functional groups have been shown to act as efficient nucleophilic catalysts. Interesting work on DBU catalyst has provided excellent control over the architecture of linear and stars PLLA polymer chains.

The main objective of the present work is to study ROP of L-lactide at room temperature using DBU as an organocatalyst to develop polymerization rate and narrow molecular weight distribution (MWD) of PLLA during the ROP of L-Lactide because most experiments mentioned in the literature were carried out at high temperatures ranging from temperature $\left(150-190^{\circ} \mathrm{C}\right)$ using organocatalyst [12-14,23] or catalysts containing metals [27]. Using DBU in ROP at room temperature is provided conventional easy condition to develop a standardized synthetic procedure hopefully applicable to a wide range of catalyst systems. DBU as an organic base of low nucleophilicity that has found wide application as a catalyst for transesterification-like reactions at room temperature, with impressive effectiveness to afford polylactide that has defined structure, controlled molecular weight, and molecular weight distribution. To investigate systematically the effect of polymer architecture on a family of PLLA polymer stars, dipentaerythritol (DPE) was selected as the core initiator based on its inherent flexibility and successful use in catalyzed polymer star syntheses [28]. The proposed polymerization mechanism was steered by the hydrogen bonding interaction which is agreed well with Chuma et al [29]. This is following the fact that DBU does not cause extensive transesterification of PLLA on the time scale of lactide ROP [30].

The 6 primary hydroxyl groups of DPE are expected to initiate the polymerization of lactide. The resulting polymer is expected to have 6 arms terminated with secondary hydroxyl groups. Whether all 6 hydroxyl groups of DPE are reacted to form a six-armed polymer can be investigated by analyzing them using (FTIR, ${ }^{1} \mathrm{H}-\mathrm{NMR}$ and ${ }^{13} \mathrm{C}-\mathrm{NMR}, \mathrm{GPC}$ ) to prove the correctness of the expected structure and compositions.

\section{Characterization of the new polymers by FT-IR}

Two different techniques were utilized to examine the preparedness polymers by infrared spectroscopy depending on the physical state of the polymers. The viscous ones were cast directly on the $\mathrm{NaCl}$ disc, and the solid product was mixed with $\mathrm{KBr}$.

Dipentaerythritol-lactide polymers, which were synthesized by ROP of L-lactide monomer with dipentaerythritol as a core molecule, gave strong bands around 3500-3513 $\mathrm{cm}^{-1}$, Fig. 1, which are corresponding to the stretching of hydroxyl groups of the terminal polymerized lactide monomer. Other bands that occurred at the region around $1750 \mathrm{~cm}^{-1}$ are characteristics of stretching frequency for the ester carbonyl groups that resulted from the ring-opening of the lactide monomer. Infrared bands occurred around $1190 \mathrm{~cm}^{-1}$ which are due to stretching frequencies of (C-O) group of ester as well. Other strong bands occurred around $2950 \mathrm{~cm}^{-1}$ are attributed to the stretching of different aliphatic carbon-hydrogen bonds present $[31,32]$ as shown in Scheme 1. The intensity of the hydroxyl groups bands was decreased with increasing lactide repeated units chain length, Fig. 1, the same observation was made by Sweah et al. in the preparation of poly(ethylene glycol)-sebacatepoly(ethylene glycol) polymer chains using poly(ethylene glycol) having different molecular weight 2000, 10000 and $20000 \mathrm{~g} / \mathrm{mol}[24]$. 

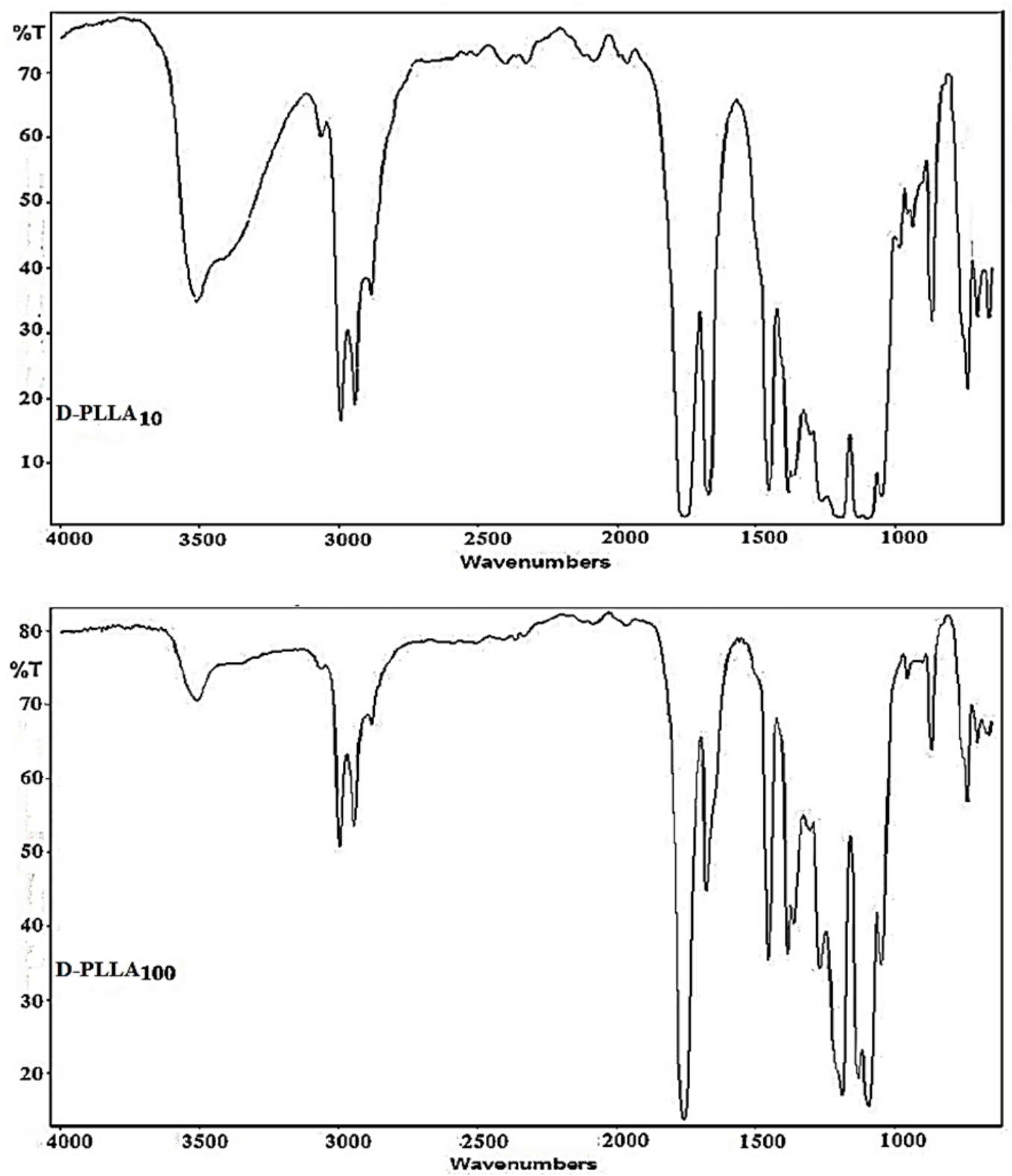

Fig. 1. Infrared spectra of the prepared D-PLLAL $L_{10}$ and D-PLLA 100 as representative polymers.

\section{Characterization of the new polymers by NMR}

${ }^{1} \mathrm{H}-\mathrm{NMR}$ and ${ }^{13} \mathrm{C}-\mathrm{NMR}$ techniques were used to confirm the structure of the newly prepared polymers (D-PLLA 10, D-PLLA 25, D-PLLA ${ }_{50}$ and D-PLLA 100$) .{ }^{1} \mathrm{H}-\mathrm{NMR}$ spectra were recorded on Agilent DDR2 500 MHz NMR spectrometers, using $\mathrm{CDCl}_{3}$ (Sigma-Aldrich, 99.8\% atom D) as a solvent.

Fig. 2 shows the representative ${ }^{1} \mathrm{H}-\mathrm{NMR}$ spectrum of D-PLLA 10 polymer. The methylene protons of $\left(\mathrm{CH}_{2}\right)$ group of dipentaerythritol appear at $3.25 \mathrm{ppm}$ (a), while the signal at $5.16 \mathrm{ppm}$ represented another methylene protons $\left(\mathrm{CH}_{2}\right)$ group of dipentaerythritol (b), the signal at $5.29 \mathrm{ppm}$ assigned to the methine protons $(\mathrm{CH})$ of repeating unit of L-lactide segments $(\mathrm{c})$, and at $1.48 \mathrm{ppm}$ represented the methyl $\left(\mathrm{CH}_{3}\right)$ protons of lactide repeated unit (d). The signal at $4.35 \mathrm{ppm}$ assigned for the methine protons $(\mathrm{CH})$ of the terminal molecule 
of L-lactide (e), and at $1.57 \mathrm{ppm}$ represented the methyl $\left(\mathrm{CH}_{3}\right)$ protons of the terminal molecule of L-lactide (f), and at $2.92 \mathrm{ppm}$ for hydroxyl groups at the end chains of polymers (g). The chemical shift at $5.05 \mathrm{ppm}$ is corresponding to the unreacted L-lactide monomer [33].
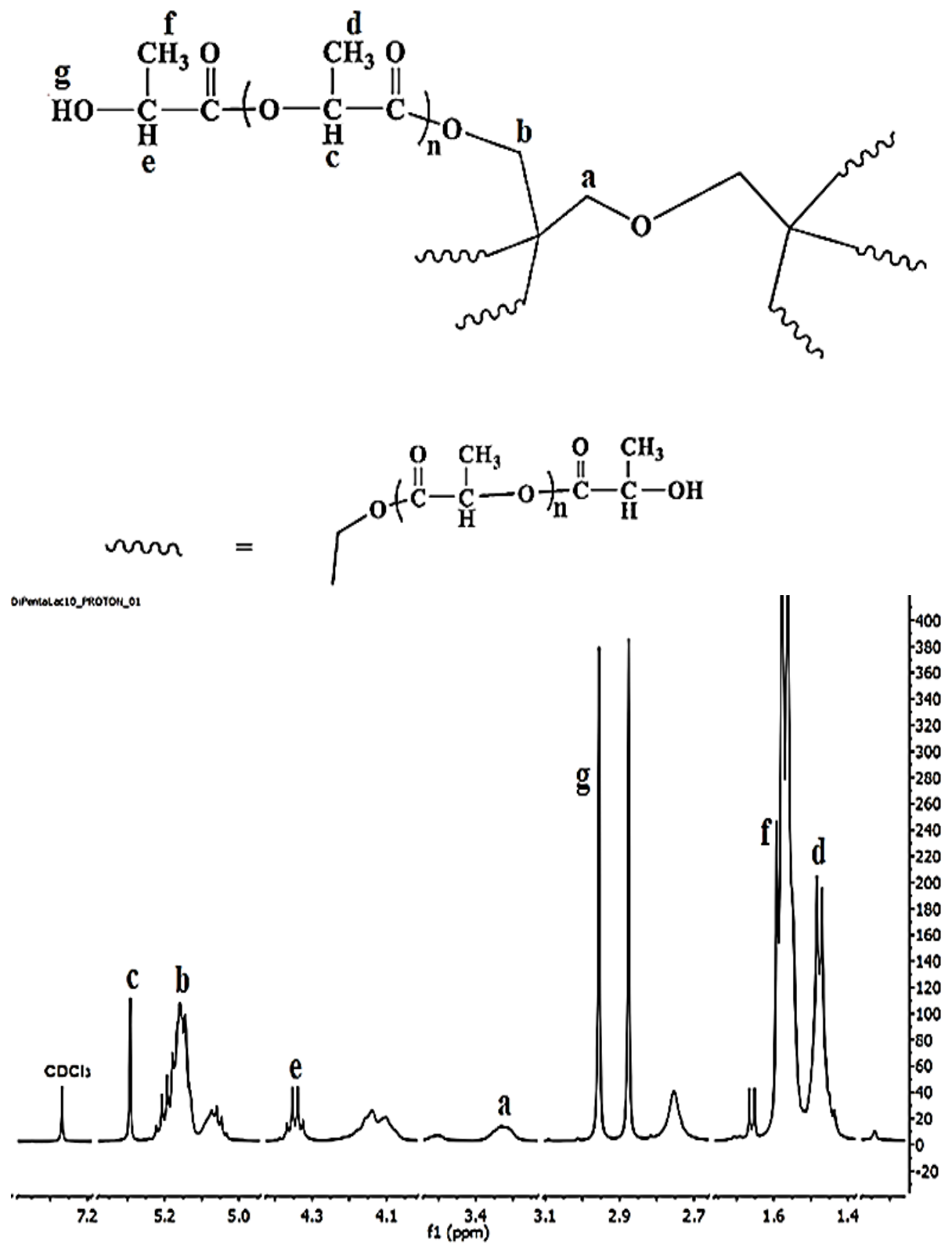

Fig. 2. Representative H-NMR spectrum of the prepared D-PLLA 10 polymer.

The ${ }^{13} \mathrm{C}-\mathrm{NMR}$ spectrum of the D-PLLA 10 polymer as a representative of the prepared polymers spectra is shown in Fig. 3. The carbon atom of a methylene group $\left(\mathrm{CH}_{2}\right)$ of dipentaerythritol appear at $36 \mathrm{ppm}(\mathrm{a})$, the signal at $63 \mathrm{ppm}$ represented the carbon atom of dipentaerythritol (b), while the signal at $67 \mathrm{ppm}$ represented another methylene carbon atom in $\left(\mathrm{CH}_{2}\right)$ group of dipentaerythritol (c), and at $170 \mathrm{ppm}$ represented the carbon 
atom of the carbonyl group of repeating unit of L-lactide (d). The signal at $17 \mathrm{ppm}$ represented the carbon atom of a methyl group $\left(\mathrm{CH}_{3}\right)$ of L-lactide (e), and at $69 \mathrm{ppm}$ for the carbon atom of methine group of repeating unit of L-lactide (f). The signal of the carbon atom of the carbonyl group of terminal L-lactide (g) appears at 175 ppm represented. The signal at $16 \mathrm{ppm}$ represented the carbon atom of a methyl group $\left(\mathrm{CH}_{3}\right)$ of terminal Llactide (h), at $72 \mathrm{ppm}$ for the carbon atom of methine group of repeating unit of terminal L-lactide (i).

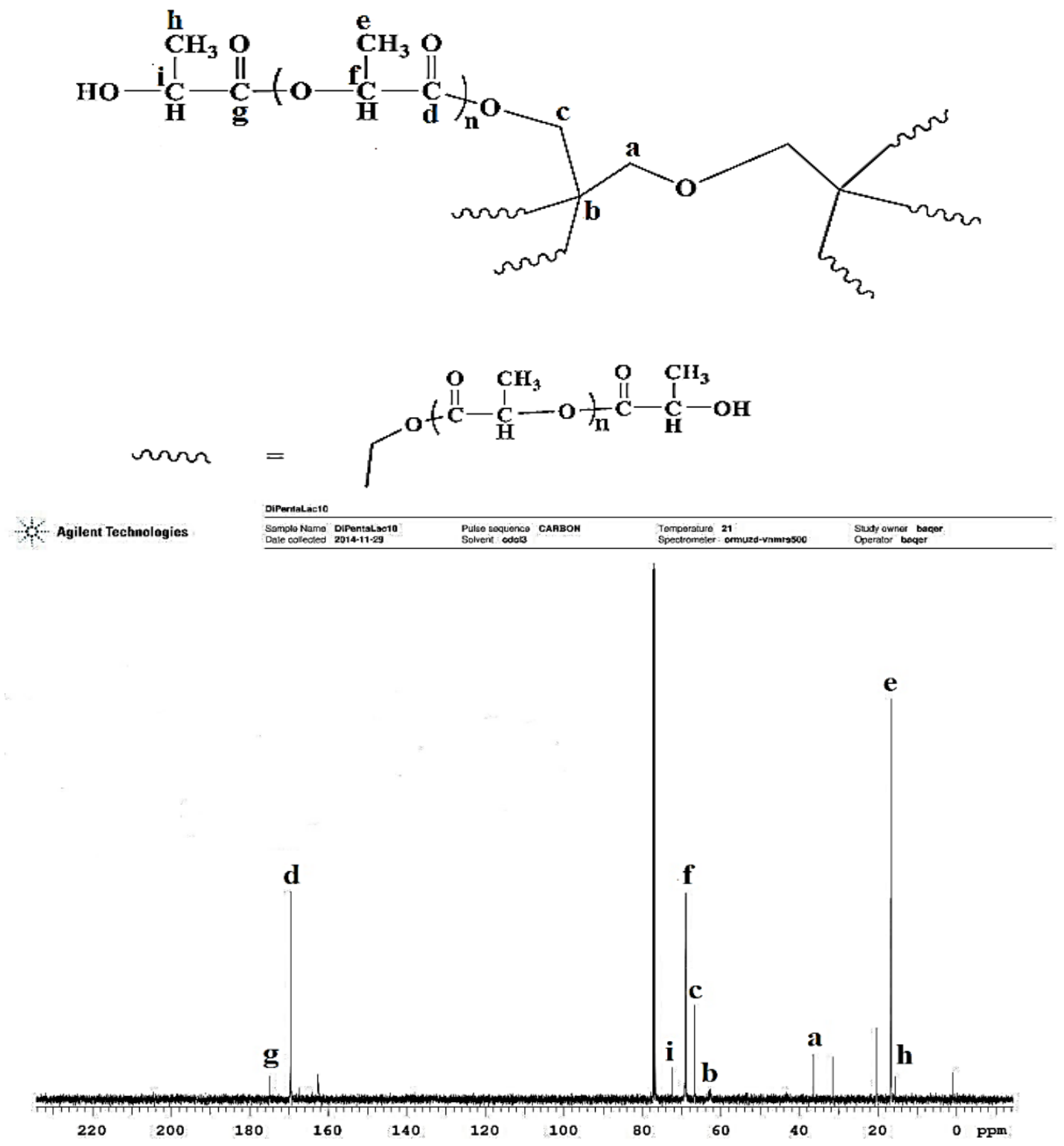

Fig. 3. Representative C-NMR spectrum of the prepared D-PLLA 10 polymer.

All these results confirmed the expected structure and composition of the prepared polymers and promoted this matter with great accuracy of the GPC results, Table 2. They are close to those calculated from the $[\mathrm{M}]_{\mathrm{o}} /[\mathrm{I}]_{\mathrm{o}}$ ratios, and their dispersity was in the range of typically observed for the ROP of lactides with the great polydispersity index (PDI) close to one. The same approached was made by Lohmeijer et al. [34] that 
DBU catalyst produced polymers displaying high-end group reliability, a good correlation between theoretical and observed molecular weight, and linear relationships between conversion and molecular weight. Although, GPC is often used to determine the relative molecular weight of polymer samples as well as the distribution of molecular weights. GPC truly measures the molecular volume and shape function as defined by the intrinsic viscosity. If comparable standards are used, as in this case PMMA standard was used, the relative data can be used to determine molecular weights within $\pm 5 \%$ accuracy [35].

Table 2. GPC results of the prepared polymers.

\begin{tabular}{|c|c|c|c|c|}
\hline Polymer Code & $\begin{array}{c}\mathrm{M}_{\mathrm{n}} \text { Calculated } \\
\left(\mathrm{gmol}^{-1}\right)\end{array}$ & $\begin{array}{c}\text { Mn Found }_{\left(\mathrm{gmol}^{-1}\right)} \\
\end{array}$ & $\begin{array}{c}\text { M }_{\mathrm{w}} \text { Found } \\
\left(\mathrm{gmol}^{-1}\right)\end{array}$ & $\begin{array}{c}\text { Polydispersity } \\
\text { Index (PDI) }\end{array}$ \\
\hline D-PLLA $_{10}$ & 4578 & 4485 & 5080 & 1.13 \\
\hline D-PLAL $_{25}$ & 11063 & 10936 & 11945 & 1.09 \\
\hline D-PLLA $_{50}$ & 21873 & 21773 & 23949 & 1.09 \\
\hline D-PLAL $_{100}$ & 43493 & 43383 & 47290 & 1.09 \\
\hline
\end{tabular}

\section{Polymer Microstructures}

The examination of the morphology and the geometry of the nanoparticles of the prepared polymers was performed by using a JEOL 7500F scanning electron microscope, SEM. Fig. 4 shows the SEM micrographs of examined D-PLLA 25 and D-PLLA 100 polymers. The images obtained from scanning electron microscopy revealed the existence of nanoparticles in the microstructure of the prepared polymers due to the presence of the L-lactide array to give nanoparticles within the final compositions $[24,25,36]$. Analysis by Image-J program of the mean nanoparticles obtained from D-PLLA 25 micrograph (Fig. 4 (A)) is in the range of (87-94) nm and from Fig. 4 (B) for D-PLLA 100 polymer is found in the range of (95-99) $\mathrm{nm}$.

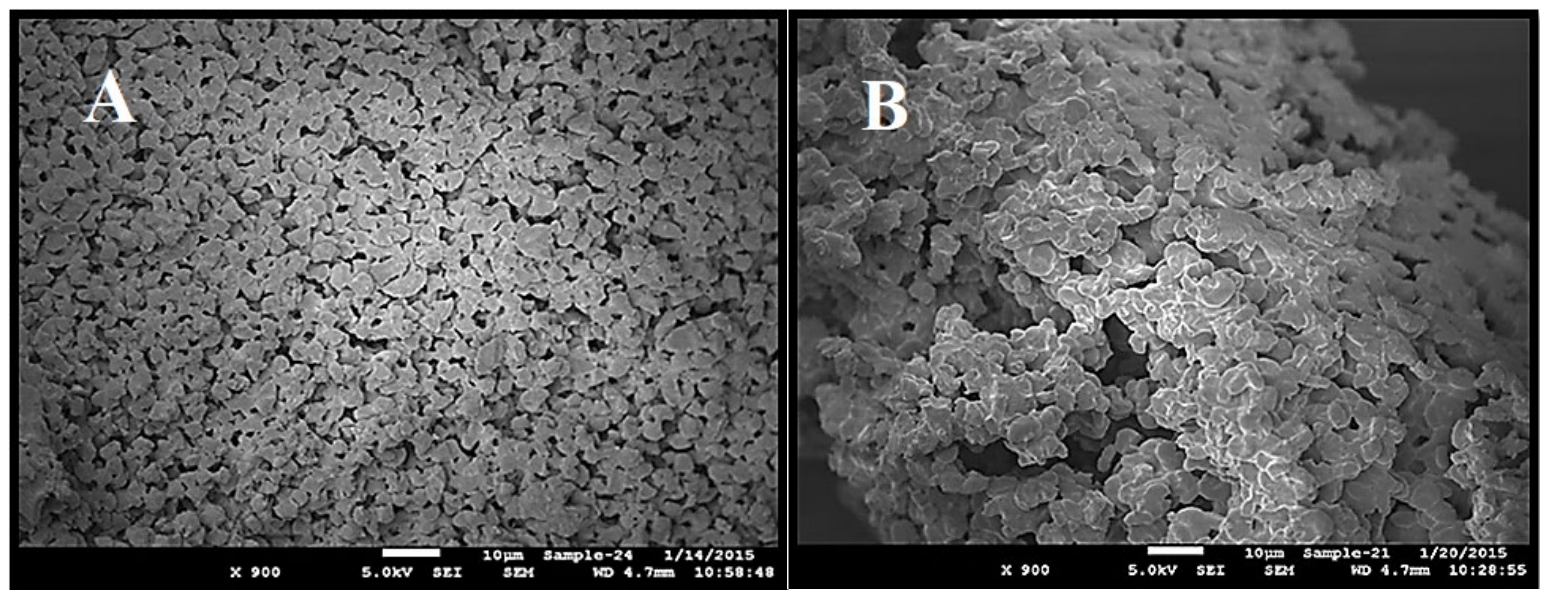

Fig. 4. SEM image of (A) D-PLLA 25 and (B) D-PLLA 100.

\section{Conclusions}

Star-shaped poly (L-lactide) with six arms having a different chain length were successfully synthesized via the ring-opening polymerization of L-lactide using a commercial dipentaerythritol as an initiator and DBU as a catalyst at room temperature. The advantage of this DBU catalyst, besides it, is free of metal, it retains high activity in the activation of multifunctional initiators and is effective in ROP of L-lactide monomer. This resulted in a convenient method for the preparation of the star-shaped D-PLLAx polymers. Moreover, the 
results revealed that there is a chance to be accurately predicted polymer molecular weight by the molar ratio of monomer to initiator implying the correctness of the expected polymer molar masses, and ensuing very low molecular weight distribution (PDIs $\leq 1.13$ ), as measured by GPC and with the right structure as characterized by FT-IR, ${ }^{1} \mathrm{H}-\mathrm{NMR}$ and ${ }^{13} \mathrm{C}-\mathrm{NMR}$ spectroscopy. This combination of initiator-catalyst was found to give reproducible results, allowing the convenient preparation of different polymer and copolymer architectures that could be useful in different means. On the other hand, images obtained from Scanning Electron Microscopy (SEM) revealed the existence of nano-structures in the prepared copolymers due to the presence of the lactide array within the final compositions prepared. As a consequence of the controlled polymerization of lactide, molecular weight, composition, chain length, and distribution of different D-PLLA polymers could be easily manipulated for different applications.

\section{References}

1. Odian, G. Principles of Polymerization, 4th ed., John Wiley \& Sons, Hoboken, N.J. 2004. DOI: https://doi.org/10.1002/047147875X

2. Rosario, M.; Ignacio, G.; Juan, R.; Giuseppe, S.; Massimo, M. Polym. Int. 2012, 61, 265-273. DOI: https://doi.org/10.1080/00986445.2018.1550395

3. Kim, S. H.; Han Y-K.; Ahn, K-D.; Kim, Y. H.; Chang, T. Die Makrom. Chemie 1993, 194(12), 32293236. DOI: http://dx.doi.org/10.1002/macp.1993.021941202

4. Srisa-ard, M.; Baimark, Y.J. Appl. Sci. 2010, 10, 1937.http://dx.doi.org/10.3923/jas.2010.1937.1943

5. Mauck, S. C.; Wang, S.; Ding, W. Y.; Rohde, B. J.; Fortune, C. K.; Yang, G.; Ahn, S.-K.; Robertson, M. L. Macromolecules 2016, 49, 1605-1615. DOI: DOI: http://dx.doi.org/10.1021/acs.macromol.5b02613

6. Swift, G. Acc. Chem. Res. 1993, 26(3), 105-110. DOI: https://doi.org/10.1021/ar00027a005

7. Itävaara, M.; Karjomaa, S.; Selin, J. F. Chemosphere. 2002, 46(6), 879-885. DOI: https://doi.org/10.1016/S0045-6535 (01)00163-1

8. Cabaret, O.; Vaca, B.; Bourissou, D. Amer. Chem. Soc., Chem. Rev. 2004, 104, 6147-6176. DOI: https://pubs.acs.org/doi/10.1021/acsmacrolett.5b00376

9. Jérôme, C.; Lecomte, P. Advan. Drug Del. Rev. 2008, 60, 1056-1076.

10. Jennifer, L. R.; Katherine B. A. J. Chem. Edu. 2008, 85(2), 258-260. DOI: https://pubs.acs.org/doi/10.1021/ed085p258

11. Dubois, P.; Coulembier O.; Raquez J. M., Eds. Handbook of Ring-Opening Polymerization. Wiley-

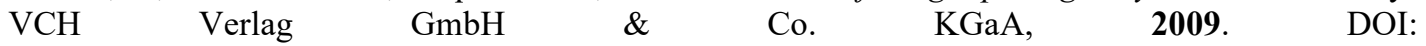
https://onlinelibrary.wiley.com/doi/book/10.1002/9783527628407

12. Cai, S.; Liu, L; Liu, X.; Liu, J. Chem. Rapid Commun., 2014, 2(1), 10-16. www.researchpub.org/journal/crc/crc.html

13. Al-Lami, H. S.; Saleh, A. A.; Jalal, M. A.; Mutasher S. H. Revista Innov. 2018, 6(1), 1-10. DOI: http://dx.doi.org/10.15649/2346075X.462

14. Kamber, N.; Jeong, W.; Waymouth, R.; Pratt, R.; Lohmeijer, B.; Hedrick, J. Am. Chem. Soc., Chem. Rev. 2007, 107, 5813-5840. DOI: https://pubs.acs.org/doi/abs/10.1021/cr068415b

15. Dove, A.; Pratt, R.; Lohmeijer, B.; Waymouth, R.; Hedrick, J., J. Am. Chem. Soc. 2005,127, 1379813799. https://pubs.acs.org/doi/abs/10.1021/ja0543346

16. Rostami, A.; Sadeh E.; Ahmadi S. J. Polym. Sci., Part A: Polym. Chem. 2017, 55(15), $2483-2493$. DOI: https://doi.org/10.1002/pola.28641

17. Pratt, R. C; Lohmeijer, B. G.; Long, D. A.; Lundberg, P. P.; Dove, A. P.; Li, H.; Wade, C. G.; Waymouth, R. M.; Hedrick, J. L. Macromolecules. 2006, 39(23), 7863-7871. DOI: https://doi.org/10.1021/ma061607o

18. Kazakov, O. I.; Datta, P. P.; Isajani, M.; Kiesewetter, E. T.; Kiesewetter, M. K. Macromolecules. 2014, 47(21), 7463-7468. DOI: http://dx.doi.org/10.1021/ma501847x

19. Mezzasalma, L.; Dove, A. P.; Coulembier, O. Eur. Polym. J. 2017, 95, 628-634. DOI: https://doi.org/10.1016/j.eurpolymj.2017.05.013 
20. Pratt, R. C.; Long, D. A.; Lohmeijer, B. G.; Waymouth, R. M; Hedrick, J. L. Polym. Prepr. 2006, 47, 151-152. DOI: https://pubs.acs.org > doi > 10.1021 > ma0619381

21. Qian, H.; Wohl, A.; Crow, J.; Macosko, C.; Hoye, T. Macromolecules 2011, 44, 7132-7140. DOI: https://doi.org/10.1021/ma201169z

22. Cameron, D. J. A.: Shaver, M. P. Chem. Soc. Rev. 2011, 40, 1761-1776. DOI: http://dx.doi.org/10.1039/c0cs00091d

23. Auras, R.; Lim, L. T.; Selke, S. E. M.; Tsuji, H. Poly (lactic acid): Synthesis, Structures, Properties, Processing, and Applications, Wiley, Hoboken, New Jersey 2010. DOI: http://dx.doi.org/10.1002/9780470649848

24. Sweah, Z. J.; Al-Lami, H. S.; Haddad, A. M. Open J. Org. Polym. Mater. 2016, 6(04), 119-133. DOI: http://dx.doi.org/10.4236/ojopm.2016.64012

25. Haddad, A., M.; Sweah, Z. J.; Al-Lami, H. S. Polym. Sci. 2017, 3(1:4), 1-8. DOI: http://imedpub.doi/10.4172/2471-9935.100019

26. Al-Mayyahi, B. A.; Haddad, A. H.; Al-Lami, H. S. Karbala Inter. J. Modern Sci. 2017, 3, 83-92. DOI: http://www.journals.elsevier.com/karbala-international-journal-of-modern-science/

27. Metkar, S.; Sathe, V.; Rahman, I.; Idage, B.; Idage, S. Chem. Eng. Commu., DOI: https://doi.org/10.1080/00986445.2018.1550395

28. Biela, T.; Duda, A.; Penczek, S. Macromolecules 2006, 39, 3710-3713. DOI: https://doi.org/10.1021/ma060264r

29. Chuma, A.; Horn, H. W.; Swope, W. C.; Pratt, R. C.; Zhang, L.; Lohmeijer, B.G. G.; Wade, C. G.; Waymouth, R. M.; Hedrick J. L.; Rice, J. E. J. Am. Chem. Soc. 2008, 130, 6749.6754. DOI: https://doi.org/10.1021/ja0764411

30. Taylor, J. E.; Bull, S. D.; Williams, J. M. J. Chem. Soc. Rev. 2012, 41, 2109-2121. DOI: https://doi.org/10.1039/C2CS15288F

31. Silverstein, R. M.; Webster, F. X.; Kiemle, D. J. (Eds), Spectrometric Identification of Organic Compounds, 7th Edition, John Wiley \& Sons Inc., New York 2005. DOI: http://bcs.wiley.com/hebcs/Books?action=index\&itemId=0470616377\&bcsId $=9100$

32. Sun, Z. J.; Chen, C.; Sun, M. Z.; Ai, C. H.; Lu, X. L.; Zheng, Y. F.; Yang, B. F.; Dong, D. L., Biomaterials, 2009, $30, \quad 5209-5214 . \quad$ DOI : https://www.sciencedirect.com/science/article/pii/S0142961209006139

33. Michalski, A.; Lapienis, G. Polymer, 2018, 63, 488-494. DOI: http://dx.doi.org/10.14314/polimery.2018.7.2

34. Lohmeijer, B. G. G.; Pratt, R. C.; Leibfarth, F.; Logan, J. W.; Long, D. A.; Dove, A. P.; Nederberg, F.; Choi, J.; Wade, C.; Waymouth, R. M.; Hedrick, J. L. Macromolecules 2006, 39, 8574-8583. DOI: https://doi.org/10.1021/ma0619381

35. Sandler, S.; Karo, W.; Bonesteel. Jo; Pearce, E. Polymer Synthesis and Characterization, Academic Press, 1st Edition 1998. DOI: https://www.elsevier.com/books/polymer-synthesis-andcharacterization/sandler/978-0-12-618240-8

36. Yang, Da-P.; Oo, M. N. L.; Deen, G. R.; Zibiao Li, Loh, X. J. Macromolecule, Rapid Commun. 2017, 1700410, 1-25. DOI: https://onlinelibrary.wiley.com/doi/10.1002/marc.201700410 